\title{
The Impact of the Mechanism of Projection on Methods of Education in Great Expectations
}

\author{
$\mathrm{Le} \mathrm{Wu}$ \\ College f Foreign Languages, University of Shanghai for Science and Technology, Shanghai, China
}

\begin{abstract}
Miss Havisham and Magwitch, who lead tragic life but adopt different manners of the mechanism of projection-egoistic manner and altruistic manner, bring about large distinction between their methods of education and exert vital influences on Estella's and Pip's fates in Great Expectations written by Charles Dickens. This paper aims to analyze the impact of ego's defence mechanism represented by the mechanism of projection on methods of education. Besides analyzing Miss Havisham's and Magwitch's life experiences for the purpose of discovering motives of their mechanisms of projection, this paper would also explore influences of their methods of education on Estella's and Pip's characters.
\end{abstract}

Index Terms-Charles Dickens, Great Expectations, the mechanism of projection, methods of education

\section{INTRODUCTION}

Among all scholars that study Great Expectations, quite a few choose to discuss characters, including Estella, Miss Havisham, Pip, Magwitch, etc. Undoubtedly, the research on the protagonist-Pip carries a big weight in all studies on Great Expectations. Yet it seems that the focus of recent studies is located more on other characters. Stanley Friedman turns to Pip's exploration of Estella's parentage and puts emphasis on the influence of her parentage on Pip (Friedman 1987). Alistair Robinson tries to study the cannibalism in Great Expectations through making a research on Magwitch's peripatetic and homeless past (Robinson 2017). Xueru ZHU's interpretation of Miss Havisham not only reflects British values in Victoria era, but also indicates woman's dependence on man in Patriarchal society (ZHU 2009). Junxia GUO studies Miss Havisham's tragic fate from three aspects: Miss Havisham's unfortunate experience of love, her morbid mentality and social causes of her tragedy (Guo 2014). Zheng Wentao and Zheng Fei finds out that Magwitch is a defender of patriarchy society after their analysis of the self-redemption progress of Magwitch (Zheng W. \& Zheng F. 2012). It could not be denied that these researches have made considerable contribution to the study of Great Expectations. But the study on Magwitch, more often than not, receives little attention. The study on the mechanism of projection of Miss Havisham and of Magwitch attracts even less critics.

This paper is disposed to study on the impact of mechanism of projection on teaching methods by taking Miss Havisham's and Magwitch's methods of education as examples. In Anna Freud's classic monograph-The Ego and The Mechanisms of Defence published in 1936, the mechanism of projection, "conceptualised by Sigmund Freud-the founder of psychoanalysis in his letters to Wilhelm Fliess" (Quinodoz 2005), denotes a kind of defence mechanism with which human ego struggles with unconscious impulses. Anna articulates that, people could have two choices: altruistic manner or egoistic manner in the process of employing the mechanism of projection to deal with impulsive instincts (Freud, A. 1936). The impact of the mechanism of projection on family education is common in practice. Particularly, the cultivation in child's character could not get rid of it.

This paper aims to delve into motives and the impact of the mechanism of projection adopted by Miss Havisham's and Magwitch's egos on their teaching methods and on child's development. During this exploration, we could be familiar with the process how ego applies the mechanism of projection to get valuable positive attachments, and would give more inspirations for family education and child's cultivation in character. It will also deepen people's understanding of the influence of the mechanism of projection on family relationship. More importantly, this study broadens people's horizon on the interpretation of characters of Great Expectations, further enhancing "the Study on Charles Dickens".

\section{Motives of Miss Havisham's and MagWitch's Mechanisms of Projection}

While suffering from mishap, or failing to achieve some vital goal, some parents tend to "delegate to their children their projects for their own lives, in a manner at once altruistic and egoistic." (Freud, A. 1936) Parents who choose altruistic manner of the mechanism of projection and establish altruistic relations to their children, would take all things into consideration and surrender their own wishes to their children if their children are better qualified. In contrast, those parents that prefer egoistic manner are more likely to be considerate of their own instincts and gratification. Miss Havisham's and Magwitch's different teaching methods could be regarded as the result caused by different choices of manners of the mechanism of projection that they make. Their displacements of suffering result in sharp difference between Estella's and Pip's fates. 
This part would firstly introduce the motive of Miss Havisham's mechanism of projection. Miss Havisham's mother died very early and her father, a county gentleman and a brewer, loves her so much that he never says no to her. Living in such an affluent family, Miss Havisham becomes "a spoilt child" (Dickens 1861) who is unaware of morality principles and social restrictions, which gives few opportunities for her superego to operate in her psyche. Miss Havisham's id, as well as ego which is little differentiated from id, craves only pleasures, aspires to satisfactions from instinctual impulses and follows the pleasure principles. And her frequent visits to public ball meet her desire exactly. Soon, she falls in love with Compeyson who pursues her closely. Her instinctual impulses at this time are satisfied so much that she does not show any doubt about Compeyson's "love". She then immerses herself in the happiness of preparing for her wedding ceremony. What's worse, she does not take Mr Pocket's warning into consideration but kicks him out of her house with indignation. Both her ego and superego lose their control of instinctual impulse and put little pressure on id obviously. She does not wake up until the situation changes in her wedding ceremony.

"The marriage day was fixed, the wedding dresses were bought, the wedding tour was planned out, the wedding guests were invited. The day came, but not the bridegroom. " (Dickens 1861)

Her fiancé does not appear on their wedding ceremony and leaves Miss Havisham at the altar since he pursues Miss Havisham and "practised on her affection in that systematic way"(Dickens 1861) merely on the purpose of getting money from her. All "blind devotion, unquestioning self-humiliation, utter submission, trust and belief" (Dickens 1861) that Miss Havisham has for her beloved turns to be a dream. In this case, Miss Havisham's instinctual impulse guided by pleasure principle is eager to march into ego to get rid of such suffering. Her ego's mute hostility is thus intensified to deal with excessive demands of instinctual impulses which could be regarded as a kind of motive-instinctual anxiety, triggering defence mechanisms of ego. In the very beginning, her ego successfully expels those dangerous instinctual impulses back by denying the cruel reality which acts as a heavy blow that breaks her proud heart to pieces. "...she afterwards stopped all the clocks... when she recovered from a bad illness that she had, she laid the whole place waste...and she has never since looked upon the light of day."(Dickens 1861) Her ego later fights against the instinctual impulse by adopting the defence mechanism, the mechanism of projection in particular, which exerts a strong influence on both her life and her adopted daughter's life.

With the perspective of background, Magwitch has less fortune than Miss Havisham who is born with a silver spoon in her mouth. Living at the bottom of the society, he receives only the instinctual impulse conveyed from his stomach instead of any inspiration on how to strive for a gentleman life. The ways he can imagine to getting food for himself are "Tramping, begging, thieving" (Dickens 1861). Compared with Miss Havisham, Magwitch has little privilege which means that he has to comply with social restrictions and is ready to be put in jail due to his illegal behaviors. He spends almost half of his life in jail just as he describes his life to Pip "In jail and out of jail, in jail and out of jail, in jail and out of jail."'(Dickens 1861) Later, he cooperates with a professional swindler Compeyson whose business mainly involves in swindling, handwriting forging, stolen bank-note passing, etc. Their cooperation though carries on smoothly in the very beginning, is exposed in the end and they both receive sentences. Owing to their different social status, Magwitch gains a longer sentence although he is a lesser actor in crime. Ostensibly, facing this unfair sentence, Magwitch's id successfully drives into ego and the dangerous instinctual impulses are transformed into aggressive acts outside world so he swears that "I'd smash that face of his (Compeyson's)" (Dickens 1861) once he has opportunities. In fact, knowing exactly that the real factor of his tragedy is not Compeyson but social regulation at his time, he frees his instinctual wish from indignation caused by the unfair trial and seeks to be conscious and to attain gratification with the help of ego. Unfortunately, Magwich's ego is "deprived of its independence and reduced to the status of an instrument for the execution of the superego's wishes" (Freud, A. 1936) which gives rise to ego's hostility and incapacity of enjoyment. This factor, called superego anxiety by Anna Freud, acts as the motive of Magwitch's mechanism of projection. When he sees Pip nearly in same situation of his early age, he could not help projecting his instinctual impulse on Pip, hoping to protect Pip from unfair treatment by strict social regulation.

\section{IMPACT OF THE MECHANISM OF PROJECTION ON Miss HAVISHAM’s METHODS OF EDUCATION}

It may be the fact that Miss Havisham wants to save other poor girls from being hurt like her. Miss Havisham tells her lawyer Mr Jaggers that "I wanted a little girl to rear and love, and save from my fate."(Dickens 1861) But, her dark room which is full of "faded bridal relics with which it was strewn" (Dickens 1861) reminds her of her resentment repeatedly and reduces her likelihood of pursuing continuously happiness for her instinctual impulse. Her instinctual impulses shortly wage a war against her ego from time to time. So her ego begins to take the mechanism of projection and projects all her instinctual impulse on all men during teaching the girl-Estella that she adopts. Moreover, given the fact that she is not young and beautiful as she used to, she needs some help from somebody else. There is no doubt that Estella who grows more and more beautiful is better qualified than her. Her original intention that she adopts Estella just for saving the poor girl out of misery changes consequently. Miss Havisham "stole her heart away and put ice in its place" (Dickens 1861). She says to Estella "Break their hearts, my pride and hope, break their hearts and have no mercy!"(Dickens 1861) The pain she gains from being abandoned is transformed into the happiness of breaking man's heart with the help of Estella. What's worse, she attempts to mislead Pip to believe that she is the patroness of him and that she has a plan of bringing him with Estella together. Next, she observes Pip's painful countenance and enjoys herself in this game. Even though it hurts the young man, she receives gratification. Once Estella grown up, "Estella 
was set to wreak Miss Havisham's revenge on men" (Dickens 1861). Miss Havisham sends Estella "to attract and torment and do mischief" (Dickens 1861) in public balls and requires Estella to report on letters on time of her "triumph" including "the names and conditions of the men whom she (Estella) had fascinated" (Dickens 1861). Through projecting her bitterness on Estella, Miss Havisham's ego receives large gratification especially when she receives Estella's letters which report that there are more hearts broken by her plots. Just as Pip finds, "she(Miss Havisham) had done a grievous thing in taking an impressionable child to mould into the form that her wild resentment, spurned affection, and wounded pride found vengeance in"(Dickens 1861).

Exactly, Miss Havisham chooses the egoistic manner when her ego takes the mechanism of projection. She pays so much attention to her own happiness that she could not help projecting her instinctual impulse on her poor adopted daughter. What she teaches Estella is how to become proud, how to become hard, instead of how to love. Once Estella has learned pride and hardness, she praises Estella. The impact of this kind of education on Estella could be found from Pip's words: "her baby intelligence was receiving its first distortions from Miss Havisham's wasting hands."(Dickens 1861)

In Pip's first appearance in Satis, Estella impresses him with her pride by calling him "boy" again and again though "she was of about my own age"(Dickens 1861). She even makes Pip consider that "she was as scornful of me as if she had been one-and-twenty, and a queen.”(Dickens 1861) Moreover, when Miss Havisham requires Estella to play with Pip, Estella refuses and says "Why, he is a common labouring-boy" (Dickens 1861). Being tired of Miss Havisham's arrangement, Estella becomes passive to Miss Havisham's "fierce affection" (Dickens 1861). She begins to detach herself and shows pride to Miss Havisham. Estella's pride even brings about a conflict with Miss Havisham. She questions Miss Havisham about her unfair treatment and tells Miss Havisham not to ask for anything that she does not give to Estella.

In order to escape from her tragic experience, Miss Havisham shuts out the light of day as well as everything that might heal her scars, resulting in "her mind, brooding solitary, had grown diseased"(Dickens 1861). Being situated in such a dark space, Estella's psyche development is affected adversely. She never knows there is daylight in the world and does not see Miss Havisham's face under sun. Under this living environment, Estella possesses hardness to others. When Miss Havisham accuses Estella of her cold heart, Estella "preserving her attitude of indifference" (Dickens 1861) and says "I am what you have made me." (Dickens 1861) What's worse, she denounces Miss Havisham's education, "...if you had taught her, from the dawn of her intelligence with you utmost energy and might, that there was such a thing as daylight, but that is was made to be her enemy and destroyer... if you had done this, and then, for a purpose, had wanted her to take naturally to the daylight and she could not do it, you would have been disappointed and angry?"(Dickens 1861) No matter how passionately Pip confesses his love to Estella, she returns nothing but "You address nothing in my breast, you touch nothing there."(Dickens 1861) More importantly, Estella receives little encouragement from Miss Havisham to fight with her tough life. Therefore, Estella prefers to marry to Drummle--a brute to escape from her present life. Her marriage does not rescue her but throws her into an abyss of sorrow in the end.

Though possessing everything and leading a wealthy life, Estella lives in the dark confinement that Miss Havisham provides. Meanwhile, Miss Havisham's egoistic manner of the mechanism of projection plays a key role in cultivating pride and hardness of Estella, even ruins her ability to love, indirectly bringing about the tragedy of Estella in her later life.

\section{IMPACT OF THE MECHANISM OF PROJECTION ON MAGWITCH’s METHODS OF EDUCATION}

Magwitch does not project his resentment to the little honest boy-Pip though he also leads a miserable life. On the contrary, he deems Pip as a son especially when he gets the idea that Pip who lives with his sister is also an orphan like him. Before being taken under escort to jail, he takes the responsibility for all crime of stealing food for fear that the boy would be punished, and swears that "sure as ever I spec'lated and got rich, you should get rich" (Dickens 1861). In Australia, Magwitch works very hard so as to make Pip a gentleman who will not be treated unfairly like him. From this point, Magwitch's ego surrenders impulses and leads him to choose the other manner-altruistic manner of the mechanism of projection. He, who expends all his energy in concerning Pip's expectations, instead of achieving his own goals, projects his own desire for being a gentleman onto Pip, just as he says, "If I ain't a gentleman, nor yet ain't got no leaning, I'm the owner of such."

From Magwitch's perspective, the money he earns is "only for you (Pip) to spend" (Dickens 1861). Through sharing his fortune with Pip, Magwitch gratifies his instinct. He shows his sympathy on Pip's hopes and believes that his relationship to the boy is even more intimate than that to a son. He asks Mr Jaggers to be Pip's guardian and to arrange all things for Pip's education but to keep his name as a secret. When he sees the gentleman he has made, he feels very proud and says "this is the gentleman what I made" (Dickens 1861).

His efforts do not secure Pip's gentleman life for a long time, but inspire Pip to be warmhearted to his friend Herbert. Same as Magwitch, Pip hopes his "good fortunate to reflect some rays upon him (Herbert)" (Dickens 1861). Then Pip asks Wemmick's help for fear of raising Herbert's suspicion. With the knowledge that Magwithch is his benefactor, Pip immediately realizes that Herbert's situation may be affected so he immediately looks for help from Miss Havisham to continuously support Herbert without Herbert's knowledge. Pip's efforts win Wemmick's praise “This is devilish good 
of you" (Dickens 1861). Also, Pip is glad to do something good to others and considers it as "A great event in my life, the turning point of my life, now opens on my view."(Dickens 1861) Pip's behavior signifies the fulfillment of instinctual wishes in a sublimate manner which enables him to make more contribution to the society.

Apart from what is mentioned above, Pip learns how to love under the effect of Magwitch's altruistic manner of the mechanism of projection. In Great Expectations, Magwitch cares about Pip's expectation more than his own situation and he says, "I lived rough, that you should live smooth; I worked hard, that you should be above work" (Dickens 1861). Even if Magwitch is put into jail at last, he shows his love to Pip and does not complain anything. All these efforts receive feedback. Pip makes full arrangement of rescuing Magwitch and tries to send him out of England as soon as he knows that Magwitch's return breaks the law. He insists his original plan in spite of his heavy injuries caused by Old Orlic. Hopefully, Pip visits jail frequently to stay with him and give him some comforts. Before Magwitch's death, Pip brings exciting news to him that his only daughter is still alive, which soothes him greatly. What Magwitch teaches Pip is not just how to love, but also how to be brave. After Magwitch's death, Pip is involved in huge debt dispute. Yet, Pip joins Herbert's business and works hard to pay his huge debt rather than escape from cruel reality like Estella.

Although Magwitch fails to continue his patronage on Pip later, Magwitch successfully projects his love and courage to Pip. Thanks to Magwitch, Pip becomes a more mature man who is warmhearted and grateful to people around him, and leads a happy life in the end.

\section{CONCLUSION}

Dickens' description of Miss Havisham's and Magwitch's methods of education in Great Expectations exemplifies that the mechanism of projection plays a significant role in family education and in child's development. The reason why there is such a large distinction between their performances when teaching could be easily found. Miss Havisham born in a wealthy family and living in upper-class society, does not gain privilege to get rid of suffering from others' plot. Considering more about her own feeling and hoping to defence instinctual impulse, her ego takes egoistic manner of the mechanism of projection and attributes her sorrow to all men. Miss Havisham's devil plan--to teach Estella to break man's hearts is typical evidence, which brings about deep trauma on Estella, indirectly throws her into an abyss of pain. Although she feels regretful about her fault later, she could not make any change but witnesses Estella taking a fatal step and marrying Drummle who is said to abuse her later. On the contrary, Magwitch, who lives in underclass society and has no choice but to do something illegal to put some food in his stomach, projects his desire to Pip in an altruistic manner though he suffers from unfair judge. Unlike Miss Havishham, Magwitch loves Pip and cares more about Pip's expectation and Pip's development even though he is not the father of Pip. His contribution plays an important role in Pip's growth and enlightens Pip to take a sublimate form, benefiting the whole society.

Research on the mechanism of projection in one's ego gives us a new angle to interpret impact of methods of education in Great Expectations on children so as to explore Dickens' concern for the importance of the psyche of parents reflected by the behavior of parents before children in family education. His appealing to good family education, personal psyche development, and harmonious relation with individuals, devotes greatly to build a mutual value in our society. Meanwhile, we could further understand the impact of ego's defence mechanism represented by the mechanism of projection on child's growth.

\section{REFERENCES}

[1] Dickens, Charles. (1861). Great Expectations, London: Chapman \& Hall, Hertfordshire: Wordsworth Editions Ltd, (1992).

[2] Freud, Anna. (1936). The Ego and The Mechanisms of Defence. Trans. C. Baines. (1973). New York: International Universities Press.

[3] Freud, Sigmund. (1959). Beyond the Pleasure Principle. Ontario: Penguin Books Canada Ltd..

[4] Friedman, Stanley. (1987). Estella's Parentage and Pip's Persistence: The Outcome of "Great Expectations". Studies in the Novel, Vol.19 No.4, 410-421.

[5] Gates, Sarah. (2009). Intertextual Estella: Great Expectations, Gender, and literary Tradition. PMLA, Vol.124 No. 2, $390-405$.

[6] Guo Junxia. (2014). Analysis of Miss Havisham's Tragic Life in "Great Expectations". Short Stories(Original Version), O6Z, 69-70.

[7] Quinodoz, Jean-Michel. (2005). Reading Freud. London: Taylor \& Francis Ltd., 24.

[8] Robinson, Alistair. (2017). Vagrant, Convict, Cannibal Chief: Abel Magwitch and the Culture of Cannibalism in "Great Expectations". Journal of Victorian Culture, Vol. 22 Issue 4, 450-464.

[9] Shores, Lucille P. (1998). The Character of Estella in Great Expectations. Novels for Students, Vol.4, 91-99.

[10] Zheng Wentao \& Zheng Fei. (2012). Self-redemption of Magwitch: a Corpus-based Analysis of "Great Expectations". Journal of Beijing University of Aeronautics and Astronautics (Social Sciences Edition), 25 No.2, 97-100.

[11] Zhu Xueru. (2009). The Unbearable Sorrow of life--Analysis of Miss Havisham in "Great Expectations". Masterpieces Review, $12,130-132$.

Le Wu was born in Hefei, China in 1991. She is currently a postgraduate student in the College f Foreign Languages, University of Shanghai for Science and Technology, Shanghai, China. Her research interest includes English literature and New Zealand literature. 